\title{
Penyuluhan Pencegahan Penularan Covid-19 Pada Penderita Hiv Di Rsud Dr Moewardi Surakarta
}

\author{
${ }^{1}$ Evi Nurhayatun, ${ }^{2}$ Nurhasan Agung Prabowo \\ ${ }^{1,2}$ Fakultas Kedokteran Universitas Sebelas Maret, Surakarta \\ email: ${ }^{1}$ evi.nurhayatun@staff.uns.ac.id
}

\begin{abstract}
People with HIV are susceptible to COVID-19 and if they have been exposed to COVID-19, they tend to be more severe than other populations. Kelompok Dukungan Sebaya (KDS) solo plus has problems with personal protective equipment that is not optimal, stress and anxiety, higher risk of infection and lower body resistance. Therefore, it is important to do prevention education, clean and healthy lifestyle, how to take medicine during the pandemic and recognize early symptoms of disease for people living with HIV (PLWHA/people with HIV AIDS). This community service provides a solution by providing information on COVID-19 for people with $H I V$, providing personal protective equipment and making a safety guidebook for HIV. This activity is going well and supports the prevention of transmission of COVID-19 in HIV sufferers KDS Solo Plus. Suggestions for continuing educational activities like this with a wider range of participants and more creative methods.
\end{abstract}

Keywords: Counseling; COVID-19, HIV

\begin{abstract}
Abstrak. Penderita HIV adalah penderita yang rentan terkena COVID-19 dan jika sudah terkena COVID-19, mereka cenderung lebih parah dibandingkan populasi lainnya. Kelompok Dukungan Sebaya (KDS) Solo Plus mempunyai permasalahan, yaitu pada alat pelindung diri tidak optimal, stres dan kecemasan, risiko tertular lebih tinggi, dan daya tahan tubuh yang lebih rendah. Oleh karena itu, penting dilakukan edukasi tentang pencegahan, pola hidup bersih, sehat, cara minum obat saat pandemi, dan pengenalan gejala awal penyakit pada orang yang hidup dengan HIV (ODHA). Pengabdian masyarakat ini memberikan solusi dengan cara penyuluhan COVID-19 bagi penderita HIV, pemberian alat pelindung diri, dan pembuatan buku panduan keselamatan pada penderita HIV. Kegiatan ini berjalan baik dan mendukung pencegahan penularan COVID-19 pada penderita HIV KDS Solo Plus. Saran untuk melanjutkan kegiatan edukasi seperti ini adalah dengan cakupan peserta lebih luas dan metode yang lebih kreatif.
\end{abstract}

Kata kunci: Penyuluhan; COVID-19, HIV

\section{Pendahuluan}

World Health Organization (WHO) pertama kali menyatakan COVID-19 sebagai global pandemic pada 11 Maret 2020 (WHO, 2020). Skala dampaknya diperkirakan cukup besar hingga mungkin memerlukan satu dekade bagi dunia untuk pulih secara sosial dan ekonomi, yang sangat mungkin juga secara signifikan menghambat Sustainable Development Agenda (SDGs) 2030 (United Nations, 2020).

$$
\text { Berbagai negara dihadapkan }
$$


pada tantangan menangani pandemi COVID-19. Oleh karena itu, diharuskan kerja sama yang baik dan tidak hanya pada sektor kesehatan, namun juga lintas sektor. Secara populasi, Indonesia adalah negara dengan kepadatan penduduk keempat di dunia. Karena inilah, menurut Asian Development Bank, 2020 (dikutip dari Djalante et al., 2020) (Djalante et al., 2020), diperkirakan Indonesia akan mengalami kesulitan terkait pandemi COVID-19 dan lebih lama dibandingkan negara berpenduduk lebih sedikit. Setelah pertama kali muncul di Indonesia, COVID-19 masih merupakan masalah utama di Indonesia hingga saat ini meskipun satu tahun telah berlalu. COVID-19 berefek pada berbagai bidang kehidupan seperti sosial, kultural, religi, ekonomi, pendidikan, dan tentunya beban kesehatan (Djalante et al., 2020). COVID-19 menyebabkan penurunan angka kunjungan ke rumah sakit (Prabowo et al, 2021). COVID-19 menyebabkan angka kematian (Case Fatality Rate) secara global, yakni 2,2\% untuk seluruh dunia pada tahun 2020, dengan puncak kematian terjadi pada bulan April 2020 sebanyak 7,23\% (Hasan et al., 2021).

Pada 27 Mei 2021, penderita dengan konfirmasi COVID-19 bertambah 6.278 orang pada hari itu sehingga menjadi 1.797.499 pasien. Selain itu, tingkat mortalitas pasien meningkat 136 menjadi 49.907, sedangkan penderita sembuh bertambah 3.924 menjadi 1.649.187. Minggu, 30 Mei 2021 di Provinsi Jawa Tengah, jumlah kasus terkonfirmasi yang dirawat (Kasus Aktif) sebanyak 8.943 sehingga jumlah semua penderita COVID-19 adalah 180.898, sedangkan penderita COVID-19 yang mati adalah 12.850. Pada kasus nasional, Jawa Tengah menduduki peringkat ketiga penderita COVID-19 yang dikonfirmasi dan kasus aktif peringkat kedua dari jumlah kasus meninggal karena COVID-19 (Prabowo et al., 2021).

Saat ini, terdapat lebih dari 38 juta ODHA di seluruh dunia. Meskipun 26 juta orang yang hidup dengan HIV, mereka diperkirakan menerima terapi antiretroviral (ART). Namun, sebagian besar dari mereka tidak menerima ART sehingga mereka mengalami imunosupresi yang tinggal di Afrika subSahara.

Di Indonesia sendiri, menurut data Pusdatin 2020, kasus HIV dan AIDS (Acquired Immunodeficiency Syndrome) pada tahun 2019 dilaporkan mencapai 57.813 kasus, yakni Jawa Tengah berada di posisi keempat teratas untuk kasus terbanyak HIV (5.630 kasus) dan posisi pertama terbanyak kasus AIDS (1.613 kasus) (Kemenkes RI, 2020). Terdapat kekhawatiran peningkatan risiko COVID-19 yang parah pada pasien dengan HIV/AIDS (ODHA) karena ODHA mengalami imunodefisiensi (Mirzaei, H et al., 2021). ODHA yang terinfeksi SARS-CoV-2 dengan jumlah CD4 rendah $(<200 \mathrm{sel} / \mu \mathrm{l})$, viral load tinggi, adanya infeksi opportunistic dalam 6 bulan, dan yang tidak menerima ART telah ditetapkan sebagai populasi berisiko sejak pandemi dimulai (Ambrosioni et al., 2021).

Namun, belum ada penelitian observasional besar yang secara khusus mengukur gejala, keparahan penyakit, komplikasi, multimorbiditas, dan proporsi kematian pada pasien koinfeksi COVID-19 yang dilaporkan. Selain itu, belum diketahui apakah orang dengan HIV yang stabil secara klinis dan virologis akan mengalami risiko komplikasi COVID-19 yang lebih besar daripada populasi tanpa infeksi HIV. Saat ini, data yang tersedia terutama berupa laporan kasus dan rangkaian kasus pasien koinfeksi COVID-19 dan HIV (Mirzaei et al., 2021).

Efek klinis langsung COVID-19 tidak hanya harus dipertimbangkan di tingkat individu, tetapi juga di tingkat populasi. Diperkirakan bahwa gangguan pada layanan pencegahan dan pengobatan HIV mungkin telah 
menyebabkan tingginya angka kematian HIV/ AIDS pada tahun 2020, yakni sekitar 400.000 orang. Buktinya, orang yang hidup dengan HIV mewakili sekitar $1 \%$ dari keseluruhan kasus COVID-19 yang memerlukan perawatan di rumah sakit. Sementara itu, prevalensi infeksi SARS-CoV-2 pada orang yang hidup dengan HIV berada antara $0,68-1,8 \%$, yakni serupa dengan prevalensi SARSCoV-2 (0,6-0,8\%) yang dilaporkan pada populasi umum (Ambrosioni et al., 2021).

Pada penelitian observasional prospektif di Hospital Universitario Ramón y Cajal, Madrid, hal itu menunjukkan proporsi ODHA yang dilaporkan dengan COVID-19 cenderung memiliki multimorbiditas, tingkat keparahan penyakit, dan proporsi kematian yang berpotensi lebih tinggi. Multimorbiditas ditunjukkan hampir dua pertiga pasien koinfeksi. Penyakit penyerta yang paling umum di antara pasien dengan HIV dan COVID-19 adalah hipertensi, obesitas atau hiperlipidemia, penyakit paru obstruktif kronik, dan diabetes. Hasil studi Kohort menunjukkan bahwa multimorbiditas (kebanyakan hipertensi dan diabetes) lebih banyak terjadi pada pasien koinfeksi COVID-19-HIV daripada ODHA tanpa COVID-19 (Vizcarra et al., 2020).

Mengenai gejala setelah infeksi SARS-CoV-2, sebanyak $66,5 \%$ memiliki gejala ringan, $21,7 \%$ melaporkan gejala berat, dan 11,8\% membutuhkan perawatan kritis. Namun, tingkat infeksi tanpa gejala pada ODHA kemungkinan besar diremehkan. Epidemiologi COVID-19 pada ODHA dan tumpang tindih antara kedua pandemi tersebut mungkin akan terpengaruh pada masa mendatang oleh vaksinasi SARS-CoV-2. Semua itu tergantung pada cakupan vaksin, prioritas vaksinasi untuk ODHA, dan tanggapan populasi ini terhadap imunisasi dengan berbagai vaksin yang tersedia. Meskipun semakin banyak bukti terkonsolidasi tentang COVID-19 pada populasi umum, hubungan antara COVID-19 dengan HIV masih belum diketahui secara jelas dan data di lapangan terkadang bertentangan (Ambrosioni et al., 2021).

KDS (Kelompok Dukungan Sebaya) Solo Plus merupakan tempat berkumpul sekaligus tempat singgah bagi para ODHA kawasan Solo Raya. Tempatnya terletak di Jalan Arif Rahman Hakim No. 66 Kepunton, Jebres, Surakarta. KDS Solo Plus ini memberikan pelayanan dukungan psikososial dan layanan kesehatan bagi para ODHA. Selain itu, KDS Solo Plus juga memberikan akses obat terhadap para ODHA. KDS Solo Plus adalah yayasan kemanusiaan yang berorientasi pada kegiatan ODHA.

HIV merupakan kondisi terjadi pelemahan daya tahan tubuh karena virus tersebut merusak daya tahan imun tubuh. Oleh karena itu, terjadi pelemahan daya tahan tubuh atau disebut AIDS. Lebih lanjut, ODHA kemudian terjadi, yaitu penurunan atau gangguan kualitas hidup karena kerusakan tubuh. Jadi, inilah mengapa ODHA disebut populasi yang rentan (PAPDI, 2021). Selain itu, tidak bisa dipungkiri ODHA rawan putus obat karena setiap hari pasien harus minum obat dan kemungkinan ia menarik diri dari masyarakat karena merasa berbeda. KDS Solo Plus adalah badan nonlaba yang selalu berusaha menyiapkan tempat, naungan, dan khususnya edukasi pada ODHA. Harapannya, ODHA dapat hidup dengan kualitas hidup terbaik selayaknya manusia lain dengan konsumsi ART, upaya kesehatan lain, dan dukungan antarsebaya (Pramanda, 2011).

Kegiatan yang ada di KDS Solo Plus di antaranya adalah kegiatan kumpul bersama ODHA dan OHIDHA setiap minggu terakhir pada akhir bulan. Rangkaian kegiatannya meliputi penguatan mental dan pemantauan kesehatan ODHA. Selain itu, KDS Solo Plus juga berusaha memberikan sosialisasi pada masyarakat mengenai HIV/AIDS secara lengkap dan benar 
(Pramanda, 2011).

KDS Solo Plus merupakan sebuah Yayasan yang berdiri berdasarkan Akta Notaris Debora Enny Sutanti, S.H. Nomor C-238.HT.0301- TH.2002 Tanggal 18 Maret 2002 tentang Pendirian KDS Solo Plus. KDS Solo Plus melakukan edukasi dengan mengemas berbagai kegiatan yang harapannya bisa memberikan dampak positif kepada ODHA, baik secara fisik maupun psikis, meliputi acara kumpul sesama anggota, membesuk anggota yang dirawat, pemberian bantuan dana dan penyediaan farmasi kepada ODHA. Yayasan ini diketuai oleh Emy Zulaikha (Pramanda, 2011).

Semenjak berdiri sekitar 19 tahun, KDS Solo Plus telah malaksanakan banyak kegiatan dan bekerja sama dengan banyak pihak. Saat pandemi COVID-19 saat ini, muncul beberapa masalah, baik dari anggota maupun terkait kegiatan yayasan. Setelah berkoordinasi dengan ketua KDS Solo Plus, beberapa permasalahan utama yang dialami KDS Solo Plus adalah sebagai berikut.

a. Alat pelindung diri (APD) yang saat ini ada kurang optimal. Ini disebabkan beberapa faktor, seperti kurang pengetahuan dan minimnya stok.

b. Penularan pada penyintas HIV seringkali terjadi bukan karena tertular dari paparan pasien COVID-19, tetapi karena dari teman dan keluarga.

c. Stres dan kecemasan yang meningkat. Pandemi COVID-19 ini disadari telah meningkatkan kecemasan, terutama kekhawatiran penularan. Kecemasan dan stress yang meningkat menyebabkan penurunan daya tahan tubuh sehingga rentan tertular COVID-19.

d. Sistem imun tidak optimal. Hal ini disebabkan HIV/ AIDS itu sendiri dan faktor-faktor seperti kurang olahraga, kurang nutrisi, jarang aktivitas, dan stres atau kecemasan. Hal-hal tersebut menurunkan daya tahan tubuh ODHA di KDS Solo

Plus.

Dari beberapa masalah utama ini, dapat disusun rencana untuk melakukan edukasi mengenai beberapa poin penting, seperti pencegahan COVID-19, gaya hidup baik dan bersih, penggunaan obat selama masa COVID-19, dan mengetahui tanda bahaya COVID-19 bagi ODHA. Karena ODHA adalah populasi rentan dengan sistem kekebalan yang lebih lemah dari biasanya, sangat perlu dilakukan upaya-upaya maksimal untuk mencegah penularan COVID-19 bagi para ODHA. Dalam konteks ini dipersempit lagi fokus kepada ODHA di KDS Solo Plus.

Tujuan utamanya adalah agar ODHA tetap bisa mendapatkan pelayanan kesehatan untuk penyakitnya, tanpa menambah kemungkinan infeksi lainnya, contohnya COVID-19. Selain itu, mereka bisa terlindungi dan terjamin kesehatan fisik dan psikisnya. Hal inilah yang membuat kami melakukan pengabdian dengan judul "Pencegahan Penularan COVID-19 pada Penyintas HIV di KDS Solo Plus".

\section{Metode Ilmiah}

Menjalin kerja sama dengan KDS Solo Plus dalam pelaksanaan pengabdian ini. Langkah pengabdian yang akan dilakukan meliputi perencanaan, pengumpulan bahan dan materi, dan kegiatan inti yaitu penyuluhan. Sebelum penyuluhan, telah disepakati materi yang akan dilakukan penyuluh kepada KDS Solo Plus, yakni dalam bentuk penyuluhan secara langsung dengan pembatasan jumlah peserta dan menerapkan protokol kesehatan, juga secara daring (dengan menyebarkan video melalui kanal Youtube).

Media penyuluhan yang digunakan berupa slide presentasi, video edukasi, leaflet, dan poster. Tujuan utama kegiatan ini memberikan pemahaman kepada ODHA. Upaya yang bisa dilakukan 
untuk meminimalisasi risiko penularan COVID-19 pada penderita HIV adalah dengan memberikan pengetahuan dan beberapa bantuan APD. Kegiatan ini dilakukan pada hari Senin, 12 April 2021 di Poliklinik VCT RSUD DR Moewardi Surakarta dengan peserta yang merupakan pasien poliklinik VCT. Selepas diadakan kegiatan penyuluhan, peserta diberikan waktu untuk bertanya jawab dan diskusi ringan agar materi lebih tersampaikan. Kemudian, setiap orang juga diberikan buku panduan dan leaflet.

Pada kesempatan ini dilakukan juga pengambilan data kuesioner persepsi terhadap COVID-19. Berdasarkan Health Belief Model, untuk mengetahui dasar perilaku berkaitan kesehatan yang dilakukan peserta, pengabdi sekaligus menentukan langkah ke depan dan tindak lanjut yang akan dilakukan. Kemudian, salah satu bentuk pencegahan COVID-19 adalah dengan menerapkan protokol kesehatan. Kegiatan ini dilanjutkan dengan pemberian sumbangan kelengkapan alat pelindung diri (APD) yang baik dan benar sebagai salah satu pilar protokol kesehatan. Tujuannya adalah untuk memberikan informasi bahwa manfaat APD tidak dapat diremehkan dalam upaya pencegahan COVID-19, khususnya pada ODHA.

\section{Hasil dan Pembahasan}

Pengabdian Kepada Masyarakat bertajuk Konseling COVID 19 Bagi Orang Dengan HIV (ODHA) berlangsung pada Senin, 12 April 2021 mulai pukul 08.00 hingga 10.00 . Kegiatan yang dilakukan adalah konsultasi rawat jalan di Klinik Umum VCT RS Dr Moewardi Surakarta dan sosialisasi video konsultasi melalui media online, seperti Zoom dan YouTube. Peserta yang terlibat dan terdata berjumlah 18 orang.

Penyuluhan dipandu oleh dr. Evi Nurhayatun, Sp.PD, M.Kes sebagai pembicara. Materi yang disajikan adalah pengetahuan umum COVID-19 khususnya gejala dan tanda bahaya, kaitan HIV dan COVID-19, bagaimana menghindari COVID-19 pada penderita HIV/ AIDS, dan mengenai konsumsi obat sekaligus kontrol kesehatan saat pandemi. Materi mengenai pencegahan penularan COVID-19 pada penderita HIV/ AIDS sangat ditekankan. Agar materi lebih dipahami, diadakan pula sesi tanya jawab dan diskusi ringan. Peserta cukup antusias dan merasa terbantu dengan adanya kegiatan ini. Dalam pelaksanaan penyuluhan, hal yang paling menarik minat peserta saat sesi tanya jawab adalah mengenai vaksin COVID-19 pada ODHA. Berdasarkan panduan Perhimpunan Dokter Spesialis Penyakit Dalam (PAPDI) revisi Maret 2021 (2021), pasien HIV dengan kondisi klinis baik dan minum obat ART secara teratur dapat diberikan vaksinasi COVID-19. Kondisi baik salah satunya dengan CD4 >200 sel

per $\mu L$. Maka dari itu, pasien dengan HIV/AIDS harus melakukan pemeriksaan CD4 dan konsultasi kepada dokter sebelum melakukan vaksinasi COVID-19.

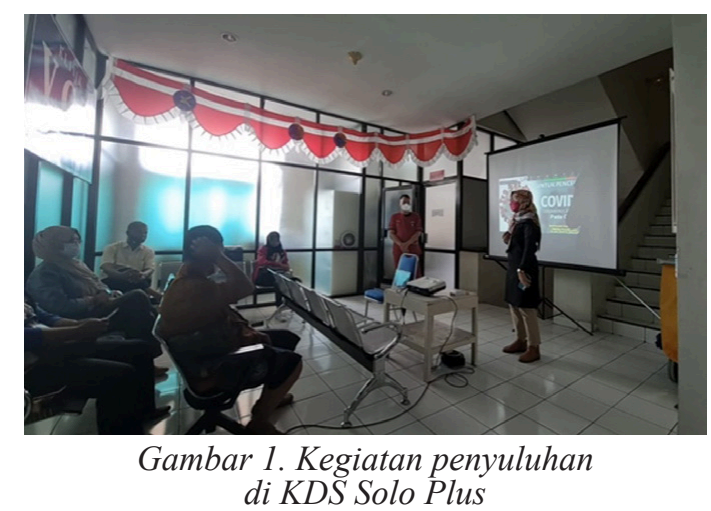

Sebelum penyuluhan dimulai, peserta diminta berpastisipasi dalam pengisian kuesioner persepsi terhadap COVID-19. Pada penyuluhan ini diambil data kuesioner berdasarkan Health Belief Model. Konsep utama dari teori ini menjelaskan perilaku manusia yang berkaitan dengan kesehatan dengan berfokus pada kepercayaan, sikap, 
dan persepsi individu mengenai suatu penyakit dan pencegahannya. Terdapat enam konstruksi utama yang menyusun teori Health Belief Model (HBM), antara lain perceived susceptibility (persepsi kerentanan), perceived severity (persepsi keparahan), perceived barriers (persepsi hambatan), perceived benefits (persepsi manfaat), self efficacy (efikasi diri), dan cues to action (isyarat untuk bertindak) (Jones et al., 2015).

Health Belief Model menyatakan bahwa individu akan melakukan tindakan mencegah penyakit atau berperilaku menjaga kesehatan jika merasa rentan terhadap suatu kondisi, percaya suatu masalah akan memiliki potensi serius/

Tabel 1. Demografi peserta penyuluhan dari anggota KDS Solo Plus (data primer)

\begin{tabular}{|c|c|}
\hline USIA & Jumlah \\
\hline \multicolumn{2}{|l|}{ 18-29 tahun } \\
\hline 30-44 tahun & 10 \\
\hline 45-60 tahun & 8 \\
\hline \multicolumn{2}{|l|}{ JENIS KELAMIN } \\
\hline Laki-laki & 12 \\
\hline Perempuan & 6 \\
\hline \multicolumn{2}{|l|}{ PENDIDIKAN TERAKHIR } \\
\hline Tidak taman sekolah / tidak tamat SD & 2 \\
\hline Taman SD / sederajat & 1 \\
\hline Tamat SMP / sederajat & 2 \\
\hline Tamat SMA / sederajat & 8 \\
\hline Perguruan Tinggi & 5 \\
\hline \multicolumn{2}{|l|}{ JENIS PEKERJAAN } \\
\hline Belum / tidak bekerja & 3 \\
\hline \multicolumn{2}{|l|}{ Pensiunan } \\
\hline \multicolumn{2}{|l|}{ TNI/POLRI } \\
\hline PNS & 2 \\
\hline Kayawan/Buruh & 4 \\
\hline Wirasyasta & 4 \\
\hline Lain-lain & 5 \\
\hline \multicolumn{2}{|l|}{ PENGHASILAN PERBULAN } \\
\hline$<$ Rp. 1.000 .000 & 9 \\
\hline Rp 1.000.000 - Rp. 2.500 .000 & 3 \\
\hline Rp 2.501.000 - Rp 5.000.000 & 3 \\
\hline$>$ Rp 5.000.000 & 11 \\
\hline
\end{tabular}

parah, percaya bahwa tindakan tertentu bisa dilakukan untuk mengurangi kerentanan/ keparahan atau memberikan manfaat positif. Jika merasakan hambatan terkait dengan kesehatan, ada keyakinan bahwa seseorang dapat melakukan perilaku yang meskipun dianggap hambatan dan adanya isyarat bertindak. Isyarat bertindak bisa muncul secara internal dan eksternal langsung melalui yang mengalami paparan atau melalui promosi kesehatan dan penyuluhan. Model ini juga menunjukkan bahwa faktor-faktor tertentu, seperti faktor internal lingkungan seseorang. Hal itu dapat berdampak pada tindakan akhir yang diambil. Kombinasi persepsi yang tepat dalam Health Belief Model mampu mempersiapkan individu untuk berperilaku sesuai anjuran kesehatan (Jones et al., 2015).

Hasil kegiatan ini menunjukkan bahwa peserta yang merupakan penderita HIV (ODHA) masih kurang percaya terhadap COVID-19 dan beberapa kurang patuh terhadap protokol kesehatan. Alasan yang dimungkinkan adalah faktor hoax yang masih banyak tersebar di kalangan masyarakat sehingga hal itu menimbulkan kebingungan kemudian pegabaian. Alasan lainnya adalah terjadinya pandemi khususnya di Indonesia telah berlangsung kira-kira satu tahun sehingga terjadi pandemic fatigue di kalangan masyarakat yang berujung pada berkurangnya kepatuhan terhadap protokol kesehatan. Dari hasil ini, edukasi masih sangat perlu dilakukan secara berkesinambungan untuk pencegahan COVID-19 pada penderita HIV/ AIDS (ODHA). Harapannya adalah melalui awalan penyuluhan ini akan timbul semangat, keingintahuan, dan kewaspadaan sekaligus ketenangan, khususnya bagi para ODHA peserta, dan ODHA pada umumnya. Selanjutnya, mereka bisa terus belajar, menyebarkan, dan menerapkan materi yang disampaikan dengan tujuan akhir memaksimalkan kualitas hidup. 


\section{Kesimpulan dan Saran}

Pengabdian masyarakat ini merupakan perwujudan solusi dari permasalahan yang dihadapi penderita HIV/ AIDS (ODHA) KDS Solo Plus, yakni dengan cara melakukan penyuluhan COVID-19 bagi penderita HIV/ AIDS (ODHA), pemberian alat pelindung diri yang baik, dan pembuatan buku panduan keselamatan pada HIV. Penyuluhan ditekankan pada upaya pencegahan COVID-19 pada ODHA melalui media presentasi, video edukasi, leaflet, dan brosur. Kemudian, dilakukan pengambilan data kuesioner mengenai COVID-19 sebelum penyuluhan. Berdasarkan Health Belifs Model didapatkan bahwa peserta yang merupakan penderita HIV/AIDS (ODHA) masih kurang percaya terhadap COVID-19 dan beberapa dari mereka kurang patuh terhadap protokol kesehatan sehingga harus digali penyebabnya sebagai evaluasi selanjutnya. Kegiatan ini berjalan baik dan peserta cukup antusias mengikutinya. Kegiatan ini turut mendukung pencegahan penularan COVID-19 pada penderita HIV/ AIDS, khususnya di KDS Solo Plus.

Saran yang bisa diberikan adalah melanjutkan kegiatan edukasi seperti ini dengan cakupan peserta lebih luas dan metode yang lebih kreatif. Selanjutnya, akan dilakukan penyuluhan secara berkala kepada keluarga atau caregiver ODHA. Sebagai populasi yang rawan karena defisiensi imun, ODHA perlu mendapat perhatian khusus utamanya dalam upaya pencegahan COVID-19.

\section{Ucapan Terima Kasih}

Ucapan terima kasih dan apresiasi kami ucapkan kepada Lembaga Penelitian dan Pengembangan Mahasiswa (LPPM) Universitas Sebelas Maret Surakarta (UNS) yang telah memberikan dukungan moral dan dana terhadap program pengabdian masyarakat ini melalui dana hibah grup pengabdian APBN UNS tahun 2021.

Selanjutnya, ucapan terima kasih dan apresiasi juga tentunya kami ucapkan kepada KDS Solo Plus yang telah bersedia untuk bekerja sama dalam kegiatan Pengabdian Kepada Masyarakat (PKM) berupa penyuluhan COVID-19 pada penderita HIV di KDS Solo Plus, mulai dari persiapan, pelaksanaan, dan setelah acara.

Terima kasih juga untuk semua pihak yang telah membantu pelaksanaan kegiatan mulai dari perencanaan hingga penyusunan artikel.

Artikel ini sudah diseminarkan pada Webinar Nasional dan Call for Paper PKM 2021.

\section{DAFTAR PUSTAKA}

Ambrosioni, J., Blanco, J. L., ReyesUrueña, J. M., Davies, M.-A., Sued, O., Marcos, M. A., Martínez, E., Bertagnolio, S., Alcamí, J., Miro, J. M., Ambrosioni, J., Blanco, J. L., de la Mora, L., Garcia-Alcaide, F., González-Cordón, A., Inciarte, A., Laguno, M., Leal, L., MartínezChamorro, E., ... Muñoz, J. (2021). Overview of SARS-CoV-2 infection in adults living with HIV. The Lancet HIV, 8(5), e294-e305. https://doi.org/10.1016/S23523018(21)00070-9

Djalante, R., Lassa, J., Setiamarga, D., Sudjatma, A., Indrawan, M., Haryanto, B., Mahfud, C., Sinapoy, M. S., Djalante, S., Rafliana, I., Gunawan, L. A., Surtiari, G. A. K., \& Warsilah, H. (2020). Review and analysis of current responses to COVID-19 in Indonesia: Period of January to March 2020. Progress in Disaster Science, 6, 100091. https://doi.org/10.1016/j. pdisas.2020.100091

Hasan, M. N., Haider, N., Stigler, F. L., Khan, R. A., McCoy, D., Zumla, A., Kock, R. A., \& Uddin, Md. J. (2021). The Global Case- 
Fatality Rate of COVID-19 Has Been Declining Since May 2020. The American Journal of Tropical Medicine and Hygiene, 104(6), 2176-2184. https://doi. org/10.4269/ajtmh.20-1496

Jones, C. L., Jensen, J. D., Scherr, C. L., Brown, N. R., Christy, K., \& Weaver, J. (2015). The Health Belief Model as an Explanatory Framework in Communication Research: Exploring Parallel, Serial, and Moderated Mediation. Health Communication, 30(6), 566-576. https://doi.org/10.1080/1 0410236.2013 .873363

Kemenkes RI. (2020). Laporan Situasi Perkembangan HIV AIDS dan PIMS di Indonesia, Triwulan IV Tahun 2019. Kementerian Kesehatan.

Mirzaei, H., McFarland, W., Karamouzian, M., \& Sharifi, H. (2021). COVID-19 Among People Living with HIV: A Systematic Review. AIDS and Behavior, 25(1), 85-92. https://doi.org/10.1007/ s10461-020-02983-2

PAPDI. (2021, March). Rekomendasi PAPDI tentang Pemberian Vaksinasi COVID-19 pada Pasien dengan Penyakit Penyerta/ Komorbid (Revisi 18 Maret 2021). https://www.papdi.or.id/berita/ info-papdi/1024-rekomendasipapdi-tentang-pemberianvaksinasi-covid-19-pada-pasiendengan-penyakit-penyertakomorbid-revisi-18-maret-2021

Prabowo, N. A., Apriningsih, H., Dirgahayu, P., Ardyanto, T. D., Hanafi, M., Indriani, A. T., Dyanneza, F., Kuncorowati, N. D. A., \& Shofiyah, L. (2021). The Decrease in Hospital Visits at Universitas Sebelas Maret Hospital Due to the Level of Stress and Fear of COVID 19: 4th International Conference on Sustainable Innovation 2020-Health Science and Nursing (ICoSIHSN 2020), Yogyakarta, Indonesia. https://doi. org/10.2991/ahsr.k.210115.021

Pramanda, A. S. (2011). PERAN DINAS KESEHATAN, LSM MITRA ALAM, DAN KDS SOLO PLUS DALAM MEMBERI PERAWATAN TERHADAP ODHA (ORANG DENGAN HIV/ AIDS) AKIBAT PENGGUNAAN NARKOBA SUNTIK JENIS PUTAW DI KOTA SURAKARTA. 115.

United Nations. (2020, March). Launch of global humanitarian response plan for COVID-19. https://www. un.org/sg/en/content/sg/pressencounter/2020-03-25/launch-ofglobal-humanitarian-responseplan-for-covid-19

Vizcarra, P., Pérez-Elías, M. J., Quereda, C., Moreno, A., Vivancos, M. J., Dronda, F., Casado, J. L., Moreno, S., Pérez-Elías, M. J., Fortún, J., Navas, E., Quereda, C., Dronda, F., Del Campo, S., López-Vélez, R., Cobo Reinoso, J., Casado, J. L., Moreno, A., Norman, F., ... Vizcarra, P. (2020). Description of COVID-19 in HIVinfected individuals: A singlecentre, prospective cohort. The Lancet HIV, 7(8), e554-e564. https://doi.org/10.1016/S23523018(20)30164-8

WHO. (2020, March). Critical Preparedness, Readiness And Response Actions for COVID-19. https://www.who. $\mathrm{int} /$ publications/i/item/criticalpreparedness-readiness-andresponse-actions-for-covid-19 